\title{
Paying the forest for electricity: a modelling framework to market forest conservation as payment for ecosystem services benefiting hydropower generation
}

THEMATIC SECTION

Payments for Ecosystem Services in Conservation: Performance and Prospects

\author{
MAURICIO E. ARIAS ${ }^{1}$, THOMAS A. COCHRANE ${ }^{1 *}$, \\ KEITH S. LAWRENCE ${ }^{2}$, TIMOTHY J. KILLEEN ${ }^{2}$ AND \\ TRACY A. FARRELL ${ }^{2}$ \\ ${ }^{1}$ University of Canterbury, Department of Civil and Natural Resources Engineering, Christchurch, Nem Zealand, \\ and ${ }^{2}$ Conservation International, 1919 M Street, NW Suite 600, Washington, DC 20036, USA
}

Date submitted: 31 October 2010; Date accepted: 23 May 2011

\section{SUMMARY}

The operation and longevity of hydropower dams are often negatively impacted by sedimentation. Forest conservation can reduce soil erosion, and therefore efforts to maintain upstream forest cover within a watershed contribute to the economic life span of a hydropower facility. The cost of forest conservation can be viewed as an investment in hydropower and be financed via a payment for ecosystem services (PES) scheme. A novel modelling framework is used to estimate payments for forest conservation consisting of: (1) land-use change projection; (2) watershed erosion modelling; (3) reservoir sedimentation estimation; (4) power generation loss calculation; and (5) PES scheme design. The framework was applied to a proposed dam in Cambodia (Pursat 1). The estimated net present value of forest conservation was US\$ 4.7 million when using average annual climate values over 100 years, or US\$ 6.4 million when considering droughts every eight years. This can be remunerated with annual payments of US\$ $4.26 \mathrm{ha}^{-1}$ or US $\$ 5.78 \mathrm{ha}^{-1}$, respectively, covering forest protection costs estimated at US\$ $0.9 \mathrm{ha}^{-1} \mathrm{yr}^{-1}$. The application of this type of PES represents a rational option that allows for conservation and development of hydropower watersheds susceptible to erosion and sedimentation.

Keymords: forest conservation, payment for ecosystem services, reservoir sedimentation, sediment yield, soil erosion, sustainable hydropower, watershed management

\section{INTRODUCTION}

Hydropower dams generate 19\% of the world's electricity (WCD [World Commission on Dams] 2000) and play an important role in avoiding global warming resulting from fossil fuels consumption. Nearly 200 gigawatts (GW) of new

\footnotetext{
*Correspondence: Thomas A. Cochrane Tel: +64 33642378 Fax:

+6433642758 e-mail: tom.cochrane@canterbury.ac.nz
}

hydropower capacity were under development around the world in 2009 (IHA [International Hydropower Association] 2010); this compares to a total existing hydropower capacity of $860 \mathrm{GW}$. Most of the present hydropower development is taking place in developing countries and emerging economies, where governments aim to: (1) improve access to electricity, especially for poor and rural communities; (2) develop domestic sources of renewable energy; (3) generate revenues in regional energy markets; and (4) lower electricity fees, in order to stimulate economic growth (King et al. 2007). Given these motivations, for many nations, hydropower development will continue to be an attractive contribution to meeting their growing energy demands. However, if dams are going to be built, they should be long-lasting and operated sustainably, in order to maximize benefits to society and minimize environmental and social impacts to local communities.

The operation and useful lifetime of dams can be seriously affected by excessive sediment accumulation. Globally, over 100 billion tonnes of sediment were trapped in reservoirs constructed in the past 50 years (Syvitski et al. 2005). Excessive sedimentation and sediment trapping is problematic from the perspective of dam operation and energy production, and impacts on hydroecological processes, such as providing nutrients for fish species and rebuilding deltas downstream. At the individual dam scale, the WCD found that $10 \%$ of studied projects lost $50 \%$ of their active storage as a result of sedimentation (WCD 2000). Sediment trapping also leads to a number of serious impacts downstream of dams, including impaired navigation, limited delivery of nutrients and increased inundation and channel erosion (Shields $e t a l$. 2002; Fu et al. 2008; Kummu et al. 2010).

Although large sediment yields can occur naturally and are sometimes accounted for in reservoir design, unforeseen high rates of erosion in the watershed can significantly reduce the profitability of hydropower facilities and cause disruptions in national energy systems. In some extreme cases, deforestation with resulting sediment delivery to reservoirs has reduced the projected useful lifespan of the facilities by as much as $50 \%$ (Hajramurni 2010). Destruction of forest cover, whether from intensive timber harvesting, agricultural conversion or mining, can significantly increase sediment yields. Moreover, the construction of a dam is often accompanied by investments in transportation infrastructure, especially in remote regions 
characterized by high forest cover and rudimentary road networks; in these instances, the probability of the conversion of land for agricultural development is significantly increased following the construction of the hydropower facility (Killeen 2007). This type of negative synergy is common in many developing nations, where hydropower development is a priority and where deforestation is an ongoing or expanding phenomenon (Bruijnzeel 2004; Syvitski et al. 2005).

One way to promote a positive synergy between conservation goals and hydropower is to value the ecosystem services from forested watersheds where dams are planned or operating. The Millennium Ecosystem Assessment (MA 2005) has recognized the following major categories of relevant ecosystem services: (1) provisioning services (products obtained from ecosystems), (2) regulating services (benefits obtained by ecosystem processes), (3) cultural services (non material benefits obtained from ecosystems), and (4) supporting services (services necessary for the production of all other ecosystem services). Among this range of services, those related to ecosystems' roles in water regulation have a relatively high economic value (Emerton 2005). Some of these services include fluvial transport, flood attenuation, water supply, erosion control, nutrient cycling and food production (Constanza et al. 1997; Emerton 2005). Numerous studies have estimated the value of ecosystems providing water-related services, including storm protection by coastal wetlands (Badola \& Hussain 2005; Costanza et al. 2008), agricultural and fisheries productivity from floodplain wetlands (Emerton 2005) and waste treatment by freshwater wetlands (Ton et al. 1998).

Although procedures to evaluate and quantify ecosystem services vary, Emerton (2005) has identified six general steps to be followed when valuing ecosystems services related to water: (1) identifying and defining the economic benefit of the ecosystem; (2) quantifying the actual value of the ecosystem service; (3) modelling ecosystem changes as a response to management changes; (4) determining the effect of these change on the value of the service provided; (5) expressing changes in ecosystem value as a response to management; and (6) identifying economic and financial measures to ensure proper ecosystem management.

Water-related ecosystem services from forested watersheds around the world have been evaluated as part of the Natural Capital Project (see URL http://www.naturalcapitalproject. org). The project team developed a toolbox, called InVEST, which helps map and model different ecosystem services. Hydropower production is modelled as a function of landscape water yield and water depth in the reservoir. Reservoir sediment accumulation is addressed by calculating the costs associated with removal of sediment from the reservoir, but not directly associated with loss in power generation related to reductions in reservoir volume (Tallis et al. 2010).

A number of studies have estimated the value of protecting forested watersheds in developing countries. The value of tropical forest ecosystems is US\$ $15-850 \mathrm{ha}^{-1} \mathrm{yr}^{-1}$ from benefits such as soil loss prevention, water for irrigation, flood protection, drought mitigation and forestry (Pearce 2001). However, the benefits from hydropower generation documented by Pearce (2001) consisted only of a single evaluation of the benefits and costs of total protection versus reduced logging of a watershed in Peninsular Malaysia, originally reported by Mohd Shahwahid et al. (1997). Services and goods from both timber and water were important, and may have had a range of other benefits, but, in Pearce's (2001) study, the value of the timber produced outweighed that of forest protection for hydropower production; Pearce's study cannot be extrapolated to other forested watersheds because of the unique configuration of both the dam and water supply system (Mohd Shahwahid et al. 1997).

In Costa Rica, a payment for ecosystem services (PES) agreement was successfully negotiated between a 6 megawatt (MW) private hydropower operator and the upper watershed's landowner (Rojas \& Aylward 2002). A baseline payment of US\$ $10 \mathrm{ha}^{-1} \mathrm{yr}^{-1}$, adjusted annually in response to inflation and energy demand, was established based on Costa Rica's national PES policy. The hydropower facility's annual operation and management costs increased by $21 \%$ to pay the landowner for activities promoting the protection of an additional 22000 ha of upland watershed, in addition to the 3000 ha immediately surrounding the hydropower dam. The hydropower company negotiated this agreement voluntarily as they recognized the benefits of avoided sedimentation and other ecosystem services provided by the watershed.

Cruz et al. (1988) presented a practical methodology for evaluating the economic impact of watershed erosion on an agricultural water storage reservoir and a hydropower reservoir in the Philippines. They quantified three different costs associated with the impact of soil erosion on downstream reservoirs : (1) shortening of service life; (2) reduction of storage capacity; and (3) increasing costs of construction if high sedimentation levels are foreseen prior to construction. The definition of these costs was ambiguous, however, because all three were related to the same physical process of storage loss from sediment accumulation (in particular for costs 1 and 2). Despite being mutually dependent, these costs were estimated separately, without the use of numerical models to estimate soil erosion and reservoir sedimentation.

Sediment yield as a function of vegetation cover change has been estimated for various watershed geological and climate conditions. In published reports from South-east (SE) Asia, yields range from as low as $0.25 \mathrm{t} \mathrm{ha}^{-1} \mathrm{yr}^{-1}$ to as high as 35-40 $\mathrm{t} \mathrm{ha}^{-1} \mathrm{yr}^{-1}$ in tectonically active areas prone to hill slope failure (Bruijnzeel 2004). Sediment yields increase exponentially as forest cover is cleared with maximum reported values approaching $100 \mathrm{t} \mathrm{ha}^{-1} \mathrm{yr}^{-1}$ in large watersheds with mixed land use (Bruijnzeel 2004). Transformation to agricultural land and increased soil erosion under conventional tillage agricultural practices leads to high rates of sedimentation in downstream reservoirs. For example, in the Dominican Republic and China as much as $20-60 \%$ of sediments accumulated in reservoirs originated from farmed soils (Lamb \& Gilmour 2000; Nagle 2002). 
Soil erosion and sediment yield for a given watershed can be estimated via direct measurements or numerical modelling. Direct measurements typically involve monitoring of water flows, sediment concentrations, and turbidity to create rating curves of sediment load and water flows (Cochrane et al. 2004) or by tracing radioactive isotopes observed in the eroded soils and reservoir sediments (Lu \& Higgitt 2001; Nagle 2002; Sadiki et al. 2007; Zheng et al. 2007). Numerical models that predict or estimate soil erosion, such as the universal soil loss equation (USLE) and its revised version (RUSLE) are widely used when data from direct measurements are lacking, or to estimate the potential for soil erosion to produce sediments in a given watershed (Renard et al. 1994).

Sediment trapping efficiency can be estimated by two methods: (1) measuring the difference between sediment input and output of the reservoir (or pre and post dam construction), or (2) calculating the nominal residence time of reservoirs, which is the ratio between storage capacity and flow rate into the reservoir. The first technique was used to estimate sediment trapping in the Upper Mekong (Lancang) River in Yunnan Province, China (Fu et al. 2008), where a mean

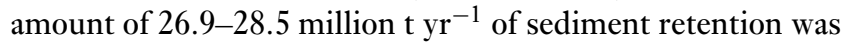
computed, which is equivalent to total storage loss of 1.88 $1.99 \% \mathrm{yr}^{-1}$ and a mean annual trapping efficiency of $60.5 \%$. The second methodology estimated a sediment trapping efficiency of $68 \%$ for the same reservoir, and estimated that the overall trapping efficiencies for five dams in the Lancang River were $61-92 \%$ (Kummu \& Varis 2007). Considering the simplicity of the second method, using the nominal residence time is a cost-effective method of providing general estimates of trapping efficiencies in the absence of sediment yield measurements.

The above suggests that (1) sedimentation is a critical issue for the operation and longevity of hydropower dams; (2) forest conservation in a watershed can significantly prevent excessive sediment yields to downstream dams; and (3) erosion control is an ecosystem service provided by forested watersheds and it offers value to downstream hydropower generation. Hence, a regulatory or market-based system that monetizes the value from ecosystem services could generate revenues to finance upstream forest conservation and management. A standardized methodological tool that allows land managers and dam operators to evaluate the potential economic benefits from forest conservation in the context of reservoir sedimentation and the useful lifespan of a hydropower facility is thus needed.

Such a tool is necessary for countries like Cambodia, which is at a critical stage in its development trajectory; the Cambodian government must make several decisions over the next few years as to the development path it will pursue. Electricity tariffs almost twice those in neighbouring countries have limited the expansion of Cambodia's textile industry. The need for domestic supplies of affordable energy have prompted the Cambodian government to develop its hydropower options; the Cardamom Mountains have been singled out for priority investments and 10 facilities are under development, with another 10 dams proposed or under evaluation. All of these hydropower facilities will depend on the water resources of the Central Cardamom Protected Forest Mountains and the Phnom Sankos Wildlife Reserve, or nearby areas that are currently part of the forest estate. These strategically important watersheds can provide up to $50 \%$ of the nation's electrical power needs by the year 2050 and may play an important role in helping this impoverished nation overcome its historical legacy of civil conflict and reduce poverty.

Hydropower and the potential costs and benefits of dams and reservoirs are an important controversial policy topic throughout SE Asia because of the ongoing plans to develop the hydrological resources of the Mekong River (Keskinen 2008). Many of the hydropower dams in the Mekong basin are highly controversial, because they threaten the long-term aquatic productivity of the Mekong and Tonle Sap Lake (Kummu \& Sarkkula 2008). The Pursat River, for example, is of greater importance because it is a tributary of the Tonle Sap and Mekong River, but most of the proposed developments in the Cardamom Mountains are located on small rivers that drain directly into the Gulf of Thailand. All hydropower facilities have both positive and negative impacts, and the decision to pursue their development should be based on objective evaluation of those impacts, made in consultation with stakeholder groups that will be affected by their development, especially the people who reside in the areas under development.

We applied a novel modelling framework to the proposed dam on the Pursat River in Cambodia (Pursat 1) to estimate the economic value of forest conservation and sustainable forest management; the consequent reduction in sediment yields into the reservoir will benefit hydropower production. The modelling framework 'FOR-POWER' simulates contrasting levels of power generation in order to calculate the impact of a truncated lifespan on hydropower revenues. Calculated values are then used to establish a baseline for a PES scheme that would pay for forest conservation in the upstream part of the watershed that supplies water to the hydropower facility. We show how future lost revenues from a prematurely exhausted facility can be avoided by investing a small amount of money in watershed management, investment that is less than the net present value of future revenues.

\section{METHODS}

The FOR-POWER framework was applied to the proposed Pursat 1 hydropower project in Cambodia (Fig. 1), which is of high strategic significance in terms of forest conservation and hydropower development in the region. The Pursat 1 watershed area is over 111000 ha, with $84.9 \%$ forest cover, $2.7 \%$ agricultural land and $12.4 \%$ taken up by the proposed reservoir. The Pursat River originates in the Cardamom Mountains and drains into the Tonle Sap Lake and River system, which is a tributary of the Mekong River. The proposed hydropower facility would be managed as a concession under a 'build, operate and transfer model' (BOT) 


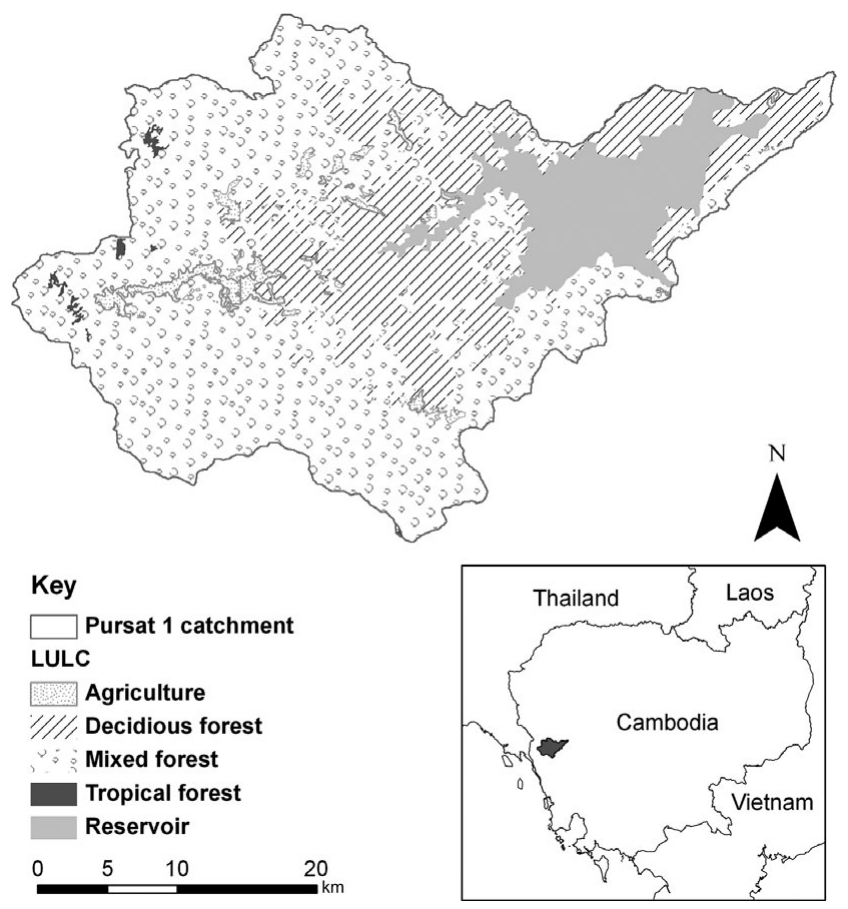

Figure 1 Pursat watershed land cover (2006) and location.

where an investor assumes responsibility to design the facility, obtains financing, oversees its construction and operates it to recover the investment and to make a profit. At the end of the BOT concessionaire period, which in Cambodia is 30 years, the facility is returned to the state.

The components of FOR-POWER include: (1) landuse change projection; (2) watershed erosion modelling; (3) reservoir sedimentation estimation; (4) power value loss calculation; and (5) PES scheme design (Fig. 2).

\section{Land-use change projection}

In order to demonstrate how a forest conservation and sustainable management programme reduces sediment yields, it was necessary to model expected land-use change under different future scenarios in the watershed. Two potential future scenarios were considered in the modelling framework: (1) a baseline forest management scenario where the current forest cover of the watershed is preserved (with deforestation $<0.01 \% \mathrm{yr}^{-1}$ ) and (2) a scenario where the watershed is deforested at or above historical rates, as defined by the user.

\section{Watershed erosion modelling}

This component of the modelling framework simulated changes in watershed soil erosion and sediment yield under the two scenarios using the geographical information system (GIS) based soil and water assessment tool (ArcSWAT), which predicts the impact of land management on water, sediment and chemical yields (Winchell et al. 2010). ArcSWAT employs a modified version of USLE to estimate sediment yield at specific hydrologic response units, namely
LAND USE CHANGE PROJECTION

Objective: to project future land coverage

Outcome: land cover maps under projected scenarios:

1) Forest management (baseline)

2) No management (deforestation)

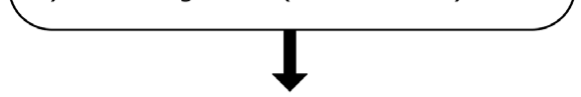

WATERSHED EROSION MODELLING

Objective: to quantify sediment yield under future scenarios of land cover

Outcome: relationship between land cover change and watershed sediment yield $(L)$

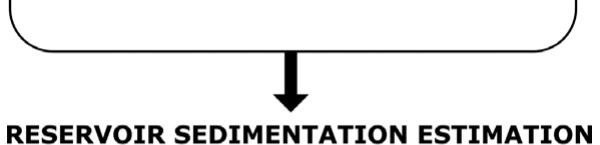

RESERVOIR SEDIMENTATION ESTIMATION

Objective: to estimate sediment trapping and accumulation in the reservoir

Outcome: estimate of reservoir storage capacity over time ( $V$ vs. time)

POWER VALUE LOSS CALCULATION

Objective: to quantify the value of the service that the forest provides to hydropower.

Outcome: annual value (VALUE), present value $(P V)$, and cumulative value ( $\left.P V_{\text {cumul }}\right)$ of the impact of forest management

\section{PES SCHEME DESIGN}

Objective: to provide payment alternatives to allocate funds for forest management

Outcome alternatives:

1) annual investment (PESannual)

2) fraction of electricity fees $(\Delta f e e)$

Figure 2 Conceptual framework (FOR-POWER) of payments for ecosystem services related to forest management and hydropower generation.

sub-watershed combinations of land-use, soil type and terrain slope class. Sediment yields were then routed through the river channel network downstream to the watershed outlet (the reservoir) via a combination of hydraulic and sediment transport routines. The data required to simulate watershed sediment yield included a digital elevation model (DEM), land coverage, soils map and climatic data.

\section{Reservoir sedimentation estimation}

Once we had estimated an annual sediment yield from the watershed, the next step was to model how much of 
the sediment was going to be trapped in the reservoir, by estimating the long-term mean trapping efficiency as a function of the ratio between storage capacity and flow rate into the reservoir (Brune 1953):

$$
T_{i}=\frac{V_{i}}{Q_{i}}
$$

where $T_{i}$ is nominal residence time of the reservoir in year $i$, $V_{i}$ is the active storage (also known as the reservoir volume between the full and low supply levels) and $Q_{i}$ is the dam design flow discharge. The sediment trapping efficiency at year $i$ can then be expressed as:

$$
T E_{i}=1-\frac{0.05 \alpha}{\sqrt{T}_{i}}
$$

where $T E_{i}$ is trapping efficiency, and $\alpha$ is an empirical constant that represents sediment particle distribution and aggregation, where $\alpha=1$ represents a medium sediment distribution that is neither highly flocculated nor colloidal in nature. This trapping efficiency method has been used extensively around the world (Kummu \& Varis 2007; Kummu et al. 2010).

It can be inferred from Eqs (1) and (2) that the volume of the reservoir would decrease as sediments accumulate, reducing $T_{i}$ and $T E_{i}$; hence, we assumed that sediments first fill up dead storage area (reservoir storage below the level of low supply) without affecting the residence time calculation (Eq. 1). However, once the dead storage is saturated, the active storage $V$ in year $i$ would be affected, such that:

$$
V_{i}=V_{i-1}-S E D_{i}
$$

where $S E D_{i}$ is the volume of sediment settled in the reservoir in year $i$. SED is found from the annual sediment yield $Y$ derived from the watershed erosion model in combination with the trapping efficiency $T E$, and the bulk density of the sediment $\rho$ :

$$
S E D_{i}=\frac{Y_{i} \times T E_{i}}{\rho}
$$

\section{Power value loss calculation}

The value of forest conservation to power generation was estimated as the difference in hydropower revenue under the two watershed management scenarios. This component of the model required basic information related to the electricity generation of the proposed dam. The expected annual revenue of the hydropower facility was calculated from the electricity tariffs in the regional or national market and the estimated mean annual energy generation under each of the two scenarios:

$$
R E V=E L E C \times G E N E R
$$

where $R E V$ is the dam's annual revenue when operating at full capacity; $E L E C$ is the electricity selling price in US\$ per kilowatt-hour (US\$ $\mathrm{kWh}^{-1}$ ); and GENER is the annual energy generation in $\mathrm{kWh}$ when the reservoir is at maximum capacity. We assumed that ELEC was constant over time in real terms. To estimate the annual loss in electricity selling revenues due to loss in reservoir storage, $\mathrm{REV}$ was multiplied by the difference in storage remaining between the two scenarios:

$$
V A L U E_{i}=R E V \times\left[\frac{V_{i, \text { conservation }}}{V_{t, \text { conservation }}}-\frac{V_{i, \text { deforestation }}}{V_{t, \text { deforestation }}}\right]
$$

where $V A L U E_{i}$ is the difference in revenues for individual years, which is essentially equivalent to the annual value of forest conservation to hydropower generation. The assumption embedded in Eq. (6) is that the revenue from a hydropower dam is proportional to its active storage capacity. This assumption simplified the calculations and allowed a more general demonstration of the concept presented in this paper.

In order to evaluate the opportunity cost of future revenues, the present value of lost energy production was estimated:

$$
P V_{i}=\frac{V A L U E_{i}}{(1+d i s c)^{i-b}}
$$

where $P V$ is the present value, disc is the annual discount rate, and $b$ is the baseline year when the analysis begins. The net present value for the lifetime of the dam was then estimated by summing up all individual present values:

$$
N P V=\sum_{n=t}^{t+100} P V_{n}
$$

where $N P V$ is the net present value of lost power generation, and thus a surrogate for the estimated value of forest conservation. This ecosystem service valuation should reflect the original expected lifetime of the dam as projected by the baseline rate of sedimentation before land-use change, which was assumed to be 100 years in this example.

\section{PES scheme design}

Once the value of the ecosystem service to future power generation was quantified, it was used to estimate the financial resources the operator of the hydropower facility should be willing to contribute towards forest conservation and management. One simple option was for the total value of the ecosystem service to be paid by equal annual instalments for the lifespan of the reservoir:

$$
P E S_{A N N U A L}=\frac{N P V}{a_{\bar{x}}}
$$

where $P E S_{A N N U A L}$ is the annual payment made by the dam operator or the government during the lifespan of the dam, 
Table 1 Pursat 1 Hydropower data used in model. All parameters from MRC (2009a) except for watershed area (estimated based on DEM).

\begin{tabular}{ll}
\hline \hline Parameter & Data \\
\hline Installed capacity $(\mathrm{MW})$ & 100 \\
Design discharge $\left(\mathrm{m}^{3} \mathrm{~s}^{-1}\right)$ & 99.2 \\
Mean energy production $\left(\mathrm{GWh} \mathrm{yr}^{-1}\right)$ & 442.9 \\
Active storage $\left(\mathrm{km}^{3}\right)$ & 0.69 \\
Watershed area (ha) & 111376 \\
\hline \hline
\end{tabular}

and $a_{\bar{x}}$ is the mean annual value of those services paid as an annuity of 1 unit per year, payable for an agreed number of years $(x)$ with payments being made at the end of each year.

The operator or regulatory authority would probably choose to pass the cost of watershed management to the electricity customer and, in that case, the equivalent payment, expressed as a cost charged per unit of electricity sold $\left(\Delta_{f e e}\right.$, in $\mathrm{US} \$ \mathrm{kWh}^{-1}$ ), is:

$$
\Delta_{f e e}=\frac{P E S_{A N N U A L}}{G E N E R}
$$

\section{Input data and application to Pursat 1}

The FOR-POWER framework was applied to the proposed Pursat 1 hydropower watershed using information from national and regional databases (Table 1 and Appendix 1, see supplementary material at Journals.cambridge.org/enc). Soils coverage and weather information were obtained from the Atlas of Cambodia (Aruna Technology 2006), while the river network, DEM, and rainfall data were obtained from the Mekong River Commission (MRC 2009a, b). A mean annual deforestation rate of $0.5 \%$, was obtained by comparing forest-cover maps produced by the Cambodian Forest Administration from Landsat images for the years 2002 and 2006, which is also the median of the range of values (0.3-0.8) published for SE Asia (Leimgruber et al. 2005; Mayaux et al. 2005; Rowcroft 2008). The watershed erosion model was developed in ArcSWAT using the soils, weather, precipitation and DEM datasets in order to simulate sediment yields under baseline conditions and as might occur on a deforested landscape, which was projected over time in a GIS by using progressive deforestation buffers around existing agricultural settlements identified on the 2006 land cover map.

A fixed electricity rate of US\$0.20 $\mathrm{kWh}^{1}$, which represents the current Cambodian electricity rate, was used to calculate the potential future revenues for the two contrasting scenarios. Future revenue loss was modified based on an annual discount rate of $10 \%$.

Two different scenarios of the Pursat 1 dam watershed were simulated: (1) a scenario where forest conservation and management take place in the watershed, preserving the baseline 2006 land-cover throughout the simulation (forest conservation); and (2) a counter factual scenario where there is a constant deforestation rate of $0.5 \% \mathrm{yr}^{-1}$ (deforestation). In addition, the FOR-POWER model was run using two climate simulation options. For the first option, average annual climate values were extrapolated for 100 years. For the second option, we assumed that droughts occurred every eight years, decreasing hydropower production by $10 \%$ and $20 \%$ under forest conservation and deforestation, respectively. This second option is justified by the fact that droughts in SE Asia occur approximately every eight years as part of the well documented ENSO phenomenon and, during this time, it is crucial to maintain appropriate hydropower capacity and production. This simulation option demonstrates how critical the value of forest conservation and management is when accounting for cyclical drought conditions that affect reservoir management. All simulations were conducted for a period of 100 years, which corresponds to the expected lifetime of the dam. A sensitivity analysis of key FOR-POWER parameters was also conducted to show how the model results might vary depending upon data availability or quality.

\section{RESULTS}

\section{Forest cover change and watershed soil erosion}

Future deforested land was estimated to cover 15\%, 24\% and $42 \%$ of the Pursat watershed area after 20, 30, and 50 years, respectively (Fig. 3). Under the baseline scenario with the 2006 land-cover map, we estimated a mean sediment

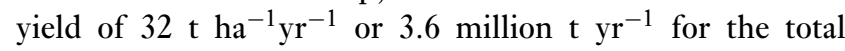
watershed using the SWAT model. When this estimate was compared to sediment yields for simulations of future land covers, annual sediment yields increased exponentially as a response to constant deforestation (Fig. 4).

\section{Reservoir sediment trapping}

Based on the proposed reservoir discharge $\left(99.2 \mathrm{~m}^{3} \mathrm{~s}^{-1}\right)$ and active volume $\left(0.69 \mathrm{~km}^{3}\right)$, the sediment trapping efficiency of the reservoir was $99.4 \%$. Under the deforestation scenario, initial reservoir volume decreased by $50 \%$ after 80 years and by $69 \%$ after 100 years. In contrast, in the forest conservation scenario, the reservoir lost only $40 \%$ of its active volume after 100 years.

\section{Value of lost revenue from hydropower generation}

With an estimated annual energy generation (GENER) of $443 \mathrm{GWh}$ and assuming electricity tariffs of $\mathrm{US} \$ 0.20 \mathrm{kWh}^{-1}$, the annual expected revenue of the dam (REV) would be US\$ 88.6 million. This was used to estimate the annual value of lost hydropower revenue $\left(\mathrm{VALUE}_{\mathrm{i}}\right)$ and its annual present value $\left(\mathrm{PV}_{\mathrm{i}}\right)$ with a discount rate of $10 \%$ (Fig. 5a, $b$ ). When the area under the curve of the annual present values of hydropower loss revenue (Fig. 5b) is integrated, the total sum is US\$ 4.7 million (or US\$ $42.15 \mathrm{ha}^{-1}$ of watershed area), which is the 

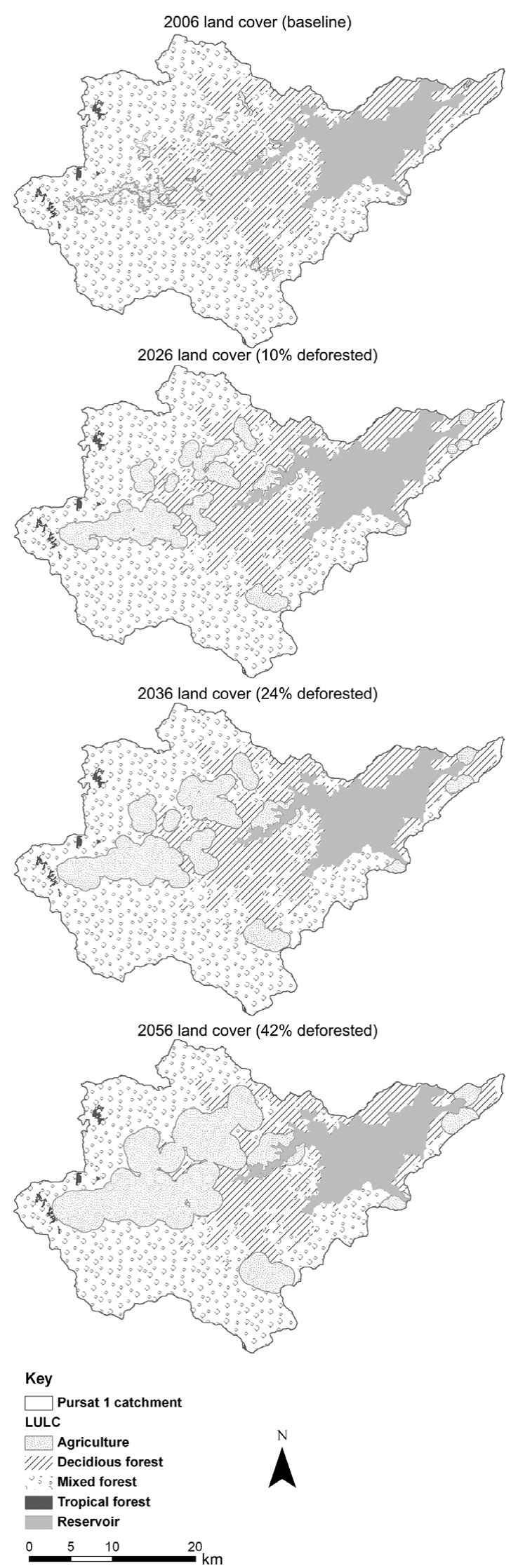

Figure 3 Baseline and projected land cover in the Pursat 1 watershed using current deforestation rates.

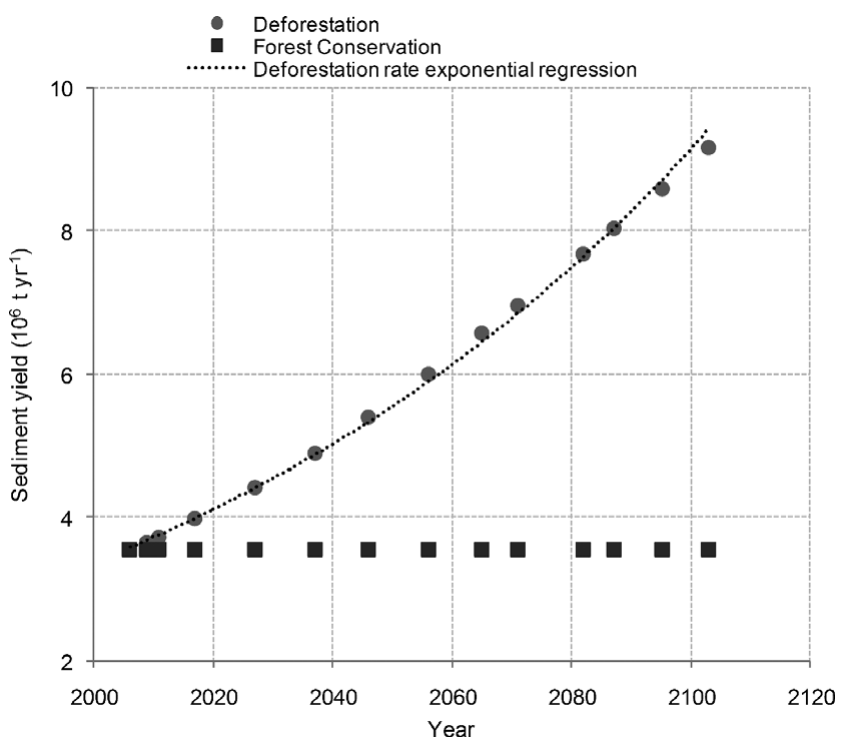

Figure 4 Watershed sediment yield (SEDi) over time assuming $0.5 \%$ annual deforestation.

NPV of forest conservation in minimizing hydropower lost revenue.

The model results show that the present value of forest conservation increases substantially during drought years (Fig. 5c). The added value during drought years results in a total NPV of US\$ 6.4 million for the dam lifespan, which is nearly $36 \%$ higher than the NPV of US $\$ 4.7$ million without climatic variability

\section{PES scheme design}

Based on the modelled value of forest conservation to hydropower production, results from three PES alternatives are proposed: $P E S_{\mathrm{ANNUAL}}, \Delta_{\text {fee }}$, and a combined approach (Table 2). When droughts are ignored equal annual payments of US\$ 475000 (PES ANNUAL ) would be required during the entire 100 years of operation. $\Delta_{\text {fee }}$ was proposed as an option to complete the appropriate PES by transferring costs directly to consumers; an additional US $\$ 0.0011$ is paid for every $\mathrm{kWh}$ charged, or an overall increase of $0.5 \%$ on the electricity fees. In the combined approach to divide payments between the private operator and government, the private operator would charge an additional electricity fee $\left(\Delta_{\text {fee }}\right)$ of US\$ $0.0006 \mathrm{kWh}^{-1}$ representing a $0.3 \%$ increase to public electricity tariffs for the first 30 years, while the government would pay a PES $S_{\text {ANNUAL }}$ of US\$219 000 for the entire 100 years.

\section{FOR-POWER framework sensitivity analysis}

Simulations were carried out under different combinations of key parameters and their impact on NPV was analysed (Table 3). Rainfall is a key input for watershed erosion simulations in SWAT and changes up to $15 \%$ in the total 
(a)

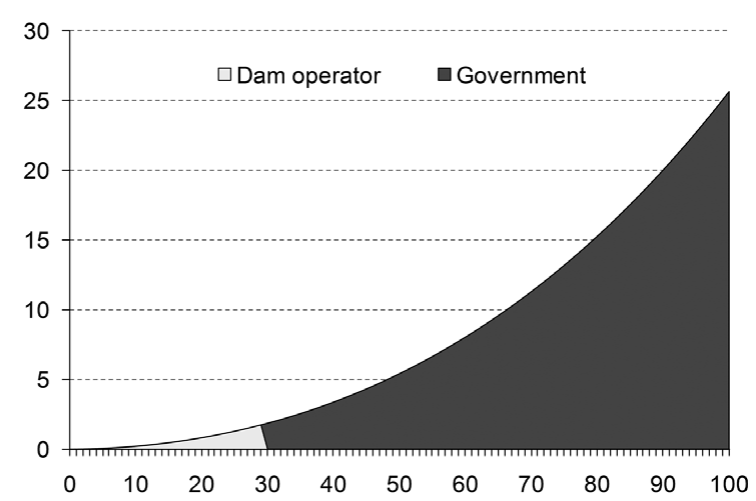

(b)

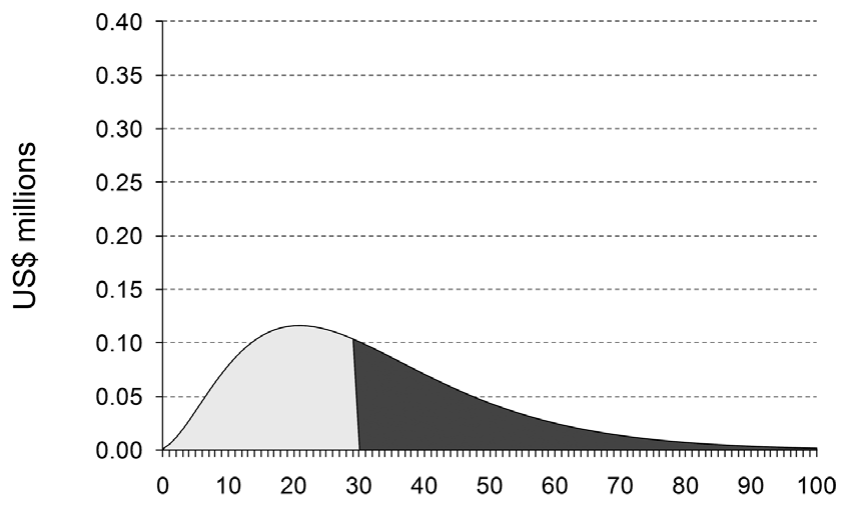

(c)

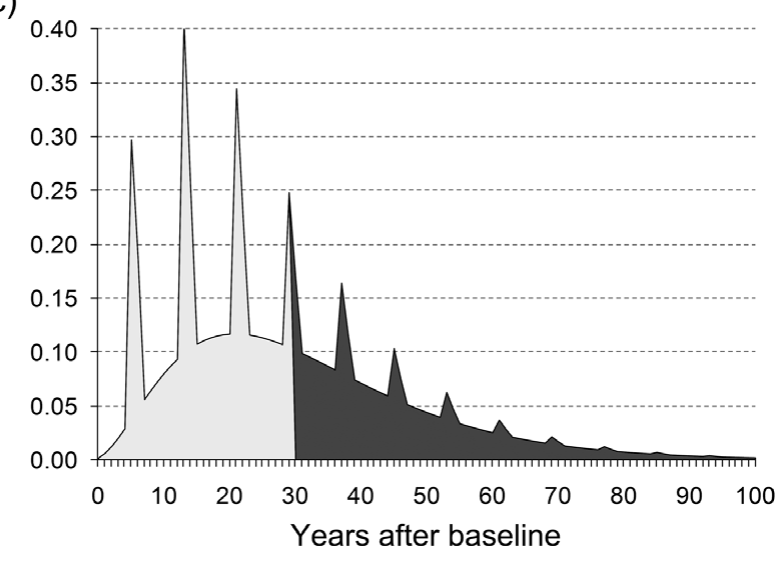

Figure 5 Value of forest conservation for dam operator (light shading) and government (dark shading) calculated as ( $a$ ) annual value of forest conservation; $(b)$ present value of forest conservation, $\mathrm{PV}$; and $(c)$ present value of forest conservation, $\mathrm{PV}$, assuming one drought every eight years.

annual rainfall can lead to variations of $40 \%$ in NPV. Much of the difference in the total rainfall between the two years of data used resulted from individual large storm events, which carried large loads of sediment from deforested areas. Increasing the reservoir trapping efficiency increases NPV (Eq. 6), which shows that VALUE is proportional to the difference in reservoir storage between the two management scenarios. Mean annual sediment trapping efficiency is expected to vary from the original value used $(99 \%)$ by no more than $3 \%$, given the expected dimensions of the
Pursat 1 reservoir (as estimated using the method developed by Brune 1953); hence, variations in the reservoir trapping efficiency would have only a minor impact on model output. The frequency of droughts had a considerable effect on the present value of forest management (Table 2 and Fig. $5 c$ ), and this should be considered when calculating PES from hydropower generation. Changes in electricity fees have a directly proportional impact on NPV; in other words, a $50 \%$ change in the electricity fees resulted in a 50\% change in NPV. The last parameter tested was the discount rate, which has a considerable effect on depreciating NPV in the long term, as shown by the sensitivity analysis.

\section{DISCUSSION}

Erosion and sedimentation modelling using the FORPOWER framework produced results that were within the expected values for rainfall, soil, cover and topography conditions of the Pursat 1 watershed within the Cardamom Mountains. The sediment yield modelled for the 2006 baseline year was within the high range of reported values for landscapes with intact forest (Bruijnzeel 2004) and is typical of areas characterized by intense rainfall events typical of monsoonal climates and areas with highly erodible soils in mountainous areas. Although the predicted sedimentation value for the Pursat reservoir seems high, it is comparable to published values calculated for a number of reservoirs in the Mekong region (Kummu \& Varis 2007; Kummu et al. 2010). These results provided a realistic baseline for valuing the lost revenues from power generation caused by sedimentation; these results can be used to establish the viability of a PES scheme.

While the annual value of lost revenues from power generation increases over time, the PV of these revenues first increases, peaks in year 21 and subsequently decreases due to discounting (Fig. 5b). This occurrence has different implications depending on the dam management scheme. Under the BOT model assumed in this paper, the private operator (in charge of the dam for the first 30 years) would be the primary beneficiary of a PES scheme, since a larger portion of the impact from forest conservation in terms of NPV would be gained during the time of concession (US\$ 2.5 million versus 2.2 million). Once the dam is transferred to the government after 30 years, the PV of the PES payment starts to depreciate considerably and therefore an amount of US\$ 475000 would be worth very little in the later years of operation. It is suggested that $P E S_{\text {ANNUAL }}$ are placed in an endowment fund since the start of dam operation to ensure that sufficient funds exist in the later years of dam operation for forest conservation.

The equal annual payments estimated in the case study for either climate input option (US\$ $4.26 \mathrm{ha}^{-1} \mathrm{yr}^{-1}$ or US\$ $5.78 \mathrm{ha}^{-1} \mathrm{yr}^{-1}$ ) were considerably lower than the baseline value of US\$ $10 \mathrm{ha}^{-1} \mathrm{yr}^{-1}$ used by Rojas and Aylward (2001) and the US\$ $12 \mathrm{ha}^{-1} \mathrm{yr}^{-1}$ suggested by Mohd Shahwahid et al. (1997). This discrepancy is mainly a result of a large 
Table 2 Comparison of payment type values for potential PES schemes under the forest conservation scenario with and without assuming one drought occurring every eight years.

\begin{tabular}{llrc}
\hline \hline Dam ownership scheme & Payment type & $\begin{array}{c}\text { Forest } \\
\text { conservation }\end{array}$ & $\begin{array}{c}\text { Forest conservation assuming } \\
\text { one drought every eight years }\end{array}$ \\
\hline Single operator for 100 yrs & $\Delta$ fee $\left(\mathrm{US} \$ \mathrm{kWh}^{-1}\right)$ & 0.0011 & 0.0015 \\
Single operator for 100 yrs & PESannual $(\mathrm{US} \$)$ & 475000 & 644000 \\
Combined approach: build, operate and & $\Delta$ fee for first 30 years $\left(\mathrm{US} \$ \mathrm{kWh}^{-1}\right)$ & 0.0006 & 0.0009 \\
$\quad$ & & & \\
transfer after 30 yrs to government & PESannual for 100 years $(\mathrm{US} \$)$ & 219000 & 253000 \\
\hline \hline
\end{tabular}

Table 3 Sensitivity analysis of FOR-POWER framework component inputs on the net present value (NPV) of lost revenue of hydropower from sediment accumulation.

\begin{tabular}{|c|c|c|c|c|}
\hline \multirow[t]{2}{*}{ Parameter } & \multicolumn{2}{|c|}{ Input } & \multicolumn{2}{|c|}{$N P V$} \\
\hline & $\overline{\text { Input unit }}$ & $\begin{array}{l}\text { Fraction of } \\
\text { original value }\end{array}$ & $\overline{U S \$ \text { millions }}$ & $\begin{array}{l}\text { Fraction of } \\
\text { original value }\end{array}$ \\
\hline \multirow[t]{3}{*}{ Annual rainfall $(\mathrm{mm})$} & 1179 & 0.85 & 3.00 & 0.64 \\
\hline & 1380 & 1.00 & 4.70 & 1.00 \\
\hline & 1580 & 1.20 & 6.60 & 1.40 \\
\hline \multirow{3}{*}{ Reservoir trapping efficiency $(\%)$} & $90 \%$ & 0.91 & 4.20 & 0.89 \\
\hline & $93 \%$ & 0.94 & 4.40 & 0.94 \\
\hline & $99 \%$ & 1.00 & 4.70 & 1.00 \\
\hline \multirow[t]{3}{*}{ Frequency of drought (yrs) } & none & - & 4.70 & 1.00 \\
\hline & 4 & - & 8.00 & 1.70 \\
\hline & 8 & - & 6.40 & 1.40 \\
\hline \multirow[t]{4}{*}{ Electricity fee $\left(\$ \mathrm{kWh}^{-1}\right)$} & 0.05 & 0.25 & 1.20 & 0.28 \\
\hline & 0.1 & 0.50 & 2.30 & 0.56 \\
\hline & 0.2 & 1.00 & 4.70 & 1.00 \\
\hline & 0.3 & 1.50 & 7.00 & 1.70 \\
\hline \multirow[t]{3}{*}{ Discount rate $(\%)$} & 8 & 0.80 & 8.90 & 2.20 \\
\hline & 10 & 1.00 & 4.70 & 1.00 \\
\hline & 12 & 1.20 & 2.80 & 0.68 \\
\hline
\end{tabular}

difference in watershed areas (5000 ha in Mohd Shahwahid et al.'s 1997 study as opposed to 111000 ha in our study area), a factor that always needs to be considered when comparing watershed protection values (Pearce 2001). The protection of watersheds also results in other ecosystem service benefits that are being provided through conservation, and as such, the benefits of watershed conservation go well beyond sustainable hydroelectricity production.

Drought can significantly reduce hydropower capacity and production and it is important to account for this periodical phenomenon to more accurately quantify the impact of forest conservation to hydropower. In this paper, droughts were incorporated in one of the FOR-POWER simulations by assuming an occurrence frequency and an associated reduction in hydropower generation during drought years. This is a preliminary attempt to account for weather variability in FOR-POWER. More accurate estimates could be achieved by incorporating a numerical model that can estimate electricity production as a function of hydrology and reservoir characteristics (for example HEC-ResSim; Klipsch \& Hurst 2007).

Any proposed PES scheme would only work if the resulting payments were sufficient to manage the forest. The actual cost of forest management to prevent future increase in erosion has not been calculated, but it appears that this cost could be fully covered by the PES scheme proposed. Currently, the cost of protecting 460000 ha of forest in the Cardamom Mountains is US $\$ 400000 \mathrm{yr}^{-1}$ (David Emmett, personal communication 2010), or US\$ $0.9 \mathrm{ha}^{-1}$ $\mathrm{yr}^{-1}$, considerably less than the PES $S_{\mathrm{ANNUAL}}$ estimated. The cost of forest protection in the Cardamoms Mountains is low due to the relative inaccessibility of this protected area, but in more disturbed watersheds where this cost becomes higher, different management schemes can be implemented to allow mixed uses and take advantage of other services offered in areas not vulnerable to erosion. It will also be important to estimate the opportunity costs of protecting the upland watershed for Pursat, compensating adequately those who would need to no longer engage in activities degrading forests and soils. Development of watershed management plans are case specific and necessary to ensure effective application of PES schemes and appropriate financial coverage for forest management. Monitoring the results of conservation interventions for their effectiveness in reducing excessive soil erosion and sedimentation, must also take place and be incorporated into adaptive management of watersheds.

The sensitivity analysis demonstrated the importance of using a modelling approach to determine lost revenues to hydropower from sediment accumulation. The fact that the model results vary considerably as a response of input 
values implies that the value of hydropower lost revenues is largely determined by specific watershed and hydropower dam characteristics. Hence, the use of standard values or rules of thumb for a wide range of hydropower projects is too simplistic; the application of a modelling framework like FOR-POWER to individual projects can yield a much more reliable hydropower loss value that can be used to justify a PES scheme.

Furthermore, the direct relationship between changes in electricity fees and NPV highlights the important role of electricity fees in the analysis presented in this paper, since these tariffs are likely to change substantially with time and with country. To gain a better understanding of tariffs, it will be necessary to apply this framework to other forested watersheds, and in the context of a larger region where the construction of multiple dams would impact future electricity rates.

\section{Current limitations and potential improvements of FOR-POWER}

The FOR-POWER framework is a straightforward tool to assess the value of forest conservation in minimizing hydropower lost revenues. Nonetheless, there are several issues that may limit its implementation more broadly. In the general context of ecosystems services, issues that can impede this practice include the lack of understanding of the benefits provided by ecosystems, high cost of transactions, absence of property rights definition, and absence of common regulators (Mulder et al. 2006). In the context of developing countries where hydropower dams are being built, good governance, social equality, willingness to pay and acceptance of principles behind the concept of ecosystem services become prerequisites to the establishment of this practice (George et al. 2009). Ensuring that these limitations are overcome is a challenge that both beneficiaries from the FOR-POWER framework, forest managers and hydropower operators must manage according to the current cultural and regulatory framework in each country (Greiber 2009).

The FOR-POWER framework requires data input from the actual beneficiaries, forested watershed managers and hydropower operators to ensure that the framework's concepts and results are understood in individual countries. Second, there needs to be a single computer interface in which practitioners can make use of this model. The case study presented was carried using two commercial interfaces, one for GIS management (ArcMap ${ }^{\mathrm{TM}}$ ) and one for spreadsheet computations (Microsoft Excel). While these two software packages are widely available, the use of a single interface would make the distribution and use of this model much simpler, especially if implemented as a web-based system. Another option would be to integrate this model to an existing ecosystem service valuation toolbox like InVEST, which quantifies benefit of forested watersheds to hydropower quite differently from FOR-POWER. Third, this framework needs to be extended to other forested watersheds around the world.
The case study of the Pursat 1 in Cambodia was presented in order to explain the framework; however, PES outcomes are only theoretical at this point. The next logical step is to develop an actual PES mechanism, refining the modelling framework, and working closely with this and other hydropower operators in the region. All of these improvements will ensure that the FOR-POWER framework becomes a well-used tool in those regions of the world where is urgently needed.

\section{CONCLUSIONS}

The new FOR-POWER framework was applied to a proposed Pursat 1 dam in Cambodia by modelling two contrasting scenarios (forest conservation and deforestation) and two input climate options, showing that forest conservation and management reduces sedimentation and provides an unrecognized and undervalued service for hydropower beneficiaries. The differences in the estimated value from the two scenarios (VALUE, PV and NPV) were used to quantify the magnitude of a proposed PES scheme for this dam. The net present value of hydropower loss due to sedimentation calculated using average yearly climatic values extrapolated over 100 years was estimated to be US $\$ 4.7$ million compared to US\$ 6.4 million when droughts are projected to occur every eight years. A PES scheme with payments of up to US\$ 4.26 and US $\$ 5.78 \mathrm{ha}^{-1} \mathrm{yr}^{-1}$ respectively, would be justified from the operator's point of view, and would more than cover the required costs of forest conservation. The FOR-POWER framework can be applied to any current and proposed dam to determine if there is a potential for a viable synergy between conservation and development in which there is little to invest and much to be gained. It provides a tool for evaluating those cost and benefits, as well as the means for developing policies to maximize those benefits over decades via an integrated watershed management strategy.

\section{ACKNOWLEDGEMENTS}

We thank the Mekong River Commission for providing much of the data used for the case study and the reviewers for their comments. Financial support was provided by Conservation International and the University of Canterbury.

\section{References}

Aruna Technology Ltd (2006) The Atlas of Cambodia: National Poverty and Environment Maps. Phnom Penh, Cambodia: Save's Cambodia's Wildlife/Danida.

Badola, R. \& Hussain, S.A. (2005) Valuing ecosystem functions: an empirical study on the storm protection function of Bhitarkanika mangrove ecosystem, India. Environmental Conservation 32(1): 85 92.

Bruijnzeel, L.A. (2004) Hydrological functions of tropical forests: not seeing the soil for the trees? Agriculture, Ecosystems and Environment 104(1): 185-228.

Brune, G.M. (1953) Trap efficiency of reservoirs. Transactions of the American Geophysical Union 34(3): 407-418. 
Cochrane, T.A., Norton, L.D., Castro, C. \& Cavigglione, J.H. (2004) Development of a river sediment transport monitoring system for large reservoirs. Applied Engineering in Agriculture 20(6): 771-781.

Constanza, R., d'Arge, R., de Groots, R., Farber, S., Grasso, M., Hannon, B., Limburg, K., Naeem, S., O’Neill, R.V., Paruelo, J., Raskin, R.G., Sutton, P.\& van den Belt, M. (1997) The value of the world's ecosystem services and natural capital. Nature 387(May 15): 253-260.

Costanza, R., Pérez-Maqueo, O., Martinez, M.L., Sutton, P., Anderson, S.J. \& Mulder, K. (2008). The value of coastal wetlands for hurricane protection. AMBIO: A Fournal of the Human Environment 37(4): 241-248.

Cruz, W., Francisco, H. \& Conway, Z. (1988) The on-site and downstream costs of soil erosion in the Magat and Pantabangan Watersheds. Fournal of Philippine Development 15(26): 85-111.

Emerton, L. (2005) Values and Remards: Counting and Capturing Ecosystem Water Services for Sustainable Development. IUCN Water, Nature and Economics Technical Paper No 1. IUCN, The World Conservation Union.

Fu, K.D., He, D.M. \& Lu, X.X. (2008) Sedimentation in the Manwan reservoir in the Upper Mekong and its downstream impacts. Quaternary International 186(1): 91-99.

George, A., Pierret, A., Boonsaner, A., Valentin, C., Orange, D. \& Planchon, O. (2009) Potential and limitations of payments for environmental services (PES) as a means to manage watershed services in mainland Southeast Asia. International Fournal of the Commons 3(1): 16-40.

Greiber, T. (2009) Payments for Ecosystem Services. Legal and Institutional Framemorks. Gland, Switzerland: IUCN.

Hajramurni, A. (2010) Makassar dam threatened by sediment, experts say. The fakarta Post May 21 [www document]. URL http://www.thejakartapost.com/news/2010/05/21/makassardam-threatened-sediment-experts-say.html

IHA (2010) Activity Report. International Hydropower Association, London, UK [www document]. URL http://www. hydropower.org/downloads/ActivityReports/IHA_Activity_ Report_2010.pdf

Keskinen, M. (2008) Water resources development and impact assessment in the Mekong Basin: which way to go? Ambio 37(3): 193-198.

Killeen, T.J. (2007) A Perfect Storm in the Amazon Wilderness, Development and Conservation in the Context of the Initiative for Integration of the Regional Infrastructure of South America (IIRSA). Applications in Applied Biodiversity Science, Volume 7. Washington, DC, USA: Conservation International.

King, P., Bird, J. \& Haas, L. (2007) The Current Status of Environmental Criteria for Hydropower Development in the Mekong Region: A Literature Compilation. Vientiane, Lao PDR: $\mathrm{ADB} / \mathrm{MRC} / \mathrm{WWF}$.

Klipsch, J.D. \& Hursh, M.B. (2007) HEC-ResSim Reservoir System Simulation User's Manual Version 3.0. Computer Program Documentation 82. Davis, CA, USA: US Army Corps of Engineers, Institute of Water Resources, Hydrologic Engineering Center.

Kummu, M., Lu, X.X., Wang, J.J. \& Varis, O. (2010) Basin-wide sediment trapping efficiency of emerging reservoirs along the Mekong. Geomorphology 119(3-4): 181-197.

Kummu, M. \& Varis, O. (2007) Sediment-related impacts due to upstream reservoir trapping, the Lower Mekong River. Geomorphology 85(3): 275-293.

Kummu, M. \& Sarkkula, J. (2008) Impact of the Mekong River flow alteration on the Tonle Sap flood pulse. Ambio 37(3): 185-192.
Lamb, D. \& Gilmour, D. (2000) A Succinct Overviem of the Issues from the Scientific Sessions as a Basis for Interfacing with Policy. UNESCO Symposium on Forest-Water-People in the Humid Tropics. Bangi, Malaysia: UNESCO.

Leimgruber, P., Kelly, D.S., Steininger, M.K., Brunner, J., Ller, T. \& Songer, M. (2005) Forest cover change patterns in Myanmar (Burma) 1990-2000. Environmental Conservation 32(4): 356364.

Lu, X.X. \& Higgitt, D. L. (2001) Sediment delivery to the Three Gorges: 2. Local response. Geomorphology 41(2): 157-169.

MA (2005) Ecosystems and Human Well-being: Synthesis. Washington, DC, USA: Island Press.

Mayaux, P., Holmgren, P., Achard, F., Eva, H., Stibig, H. \& Branthomme, A. (2005) Tropical forest cover change in the 1990s and options for future monitoring. Philosophical Transactions of the Royal Society B: Biological Sciences 360(1454): 373-384.

Mohd Shahwahid, H.O., Awang Noor, A.G., Abdul Rahim, N., Zulkifli, Y. \& Razani, U. (1997) Economic benefits of watershed protection and trade-off with timber production: a case study in Malaysia. Research Report.International Development Research Centre, Ottawa, Canada.

MRC (2009a) Hydropomer Project Database. Vientiane, Lao PDR: Mekong River Commission.

MRC (2009b) Mekong River Commission Spatial Database. Vientiane, Lao PDR: Mekong River Commission [www document]. URL http://www.mrcmekong.org/spatial/data_catalog.htm

Mulder, I., ten Kate, T. \& Scherr, S. (2006) Private sector demand in markets for ecosystem services: preliminary findings. Adapted from full report submitted to the UNDP-GEF project: Institutionalizing Payments for Ecosystem Services, supplement III. Mobilizing Private Sector Buyers for Ecosystem Services. Washington, DC, USA: Forest Trends Association.

Nagle, G.N. (2002) The contribution of agricultural erosion to reservoir sedimentation in the Dominican Republic. Water Policy 3(6): 491-505.

Pearce, D.W. (2001) The economic value of forest ecosystems. Ecosystem Health 7(4): 284-296.

Renard, K.G., Laflen, J.M., Foster, G.R. \& McCool, D. K. (1994) The revised universal loss equation. In: Soil Erosion Research Methods, ed. R. Lal, pp. 105-126. Delray Beach, FL, USA: St Lucie Press.

Rojas, M. \& Aylward, B. (2002) The Case of La Esperanza: A Small, Private, Hydropomer Producer and a Conservation NGO in Costa Rica. Land-Water Linkages in Rural Watersheds Case Study Series. Rome, Italy: FAO.

Rowcroft, P. (2008) Frontiers of change: the reasons behind land-use change in the Mekong Basin. Ambio 37(3): 213-218.

Sadiki, A., Faleh, A., Navas, A. \& Bouhlassa, S. (2007) Assessing soil erosion and control factors by the radiometric technique in the Boussouab catchment, Eastern Rif, Morocco. CATENA 71(1): 13-20.

Shields Jr, F.D, Simon, A. \& Steffen, L.J. (2002) Reservoir effects on downstream river channel migration. Environmental Conservation 27(1): 54-66.

Syvitski, J.P.M., Vörösmarty, C. J., Kettner, A.J. \& Green, P. (2005) Impact of humans on the flux of terrestrial sediment to the global coastal ocean. Science 308(5720): 376380.

Tallis, H., Ricketts, T., Nelson, E. \& Ennaanay, D. (2010) InVEST 1.005 Beta User's Guide:Integrated Valuation of Ecosystem Services and Tradeoffs. Stanford, USA: The Natural Capital Project. 
Ton, S., Odum, H.T. \& Delfino, J.J. (1998) Ecological-economic evaluation of wetland management alternatives. Ecological Engineering 11(1): 291-302.

WCD (2000) Dams and Development. A Nem Framemork for Decision-making. The Report of the World Commission on Dams. London, UK and Sterling, VA, USA: Earthscan Publications Ltd [www document]. URL http://www.unep.org/dams/ WCD/report/WCD_DAMS\%20report.pdf
Winchell, M., Srinivasan, R., Di Luzio, M. \& Arnold, J. (2010). ArcSWAT Interface for SWAT2009: User's Guide. Temple, TX, USA [www document]. URL http://swatmodel. tamu.edu/software/arcswat

Zheng, J., He, X., Walling, D., Zhang, X., Flanagan, D. \& Qi, Y. (2007). Assessing soil erosion rates on manually-tilled hillslopes in the Sichuan Hilly Basin Using 137Cs and 210Pbex measurements. Pedosphere 17(3): 273-283. 